\title{
Learning Instrument of Guided Discovery Model to Increase Science Literacy on Hydrocarbon Learning Students' Thesis
}

\author{
Olly Astria Virginia, I Gusti Made Sanjaya, and Harun Nasrudin \\ Department of Science education, postgraduate program, Universitas Negeri Surabaya \\ olly.a.virginia@gmail.com
}

\begin{abstract}
Chemistry learning is one of the processes to provide knowledge and skills about chemistry contained in nature. Understanding the concept of science-related literacy can be improved by the application of learning methods, because with a precise understanding of the concept it can provide ease, increase interest, and student motivation. In this research, it will be developed learning device of guided discovery learning model of hydrocarbon subjects in State Senior High School students. In this study, it will be described the validity, practicality, and effectiveness of learning devices based on guided discovery learning. This study was conducted using hydrocarbon learning materials with basic competence on alkanes, alkene and alkyne on chemistry subjects, with test subjects being SMA 18 students. Based on the result of this research, it can be seen that the proposed learning model for hydrocarbon material on the basic competence of alkanes, alkene, and the alkyne can be declared valid by both validator-based and practical results as seen from the results of the Lesson Plan, which is highly categorized by the observer, and effective by the improvement of mastery.
\end{abstract}

Keywords- Literacy Science, Guided Discovery Learning, Learning Devices, Learning Outcomes.

\section{INTRODUCTION}

Education is an important factor in human life. Education produces people who are qualified in knowledge and skills. Efforts to pursue education can be through formal or informal channels by which both have the same goal in providing knowledge to individuals who take it. Chemistry learning is taught to equip students with knowledge, understanding and a number of abilities needed to enter higher education and develop science and technology. Every human being can only understand the concept correctly if the basic concepts of previous science have been understood. The aim of chemistry subjects is achieved by students through various approaches; one of them in the guided discovery model.

Hydrocarbon learning is learning that requires a more conceptual understanding. Hydrocarbon learning materials learn about the formulas of compounds and reactions in hydrocarbon compounds. In hydrocarbon learning, there are also many things related to daily life. Students usually do not know the relationship between learning material with daily life, their knowledge is only based on the teaching material provided by the teacher. This can limit knowledge and make students get bored quickly during the lesson.

Science education has a great potential to enhance the strategic role in preparing human resources to face the era of globalization. This potential can be realized if science education can create competence in science learning.

Along with the times, technology and information will experience rapid development. Therefore scientific literacy is a must for everyone. According to the American Association for the Advancement of Science (1990: xvi) the world has changed so that science literacy is possible for everyone [1]. Science literacy is very important for a person because the progress of a nation is determined by the quality of human power that has literacy towards science and technology [2]. This shows that with science education is expected to have science literacy students who are accustomed to making Indonesian society more advanced and quality.

Science literacy is not only related to understanding facts but also understanding the nature of science and having the ability in Guided Discovery Learning. The results show that the learning model has an influence on scientific literacy. In this study, it was proven that the Guided Discovery learning model had a significant influence on scientific literacy [3]. The test results show that there are differences in the influence of high, medium, and low naturalist intelligence categories on scientific literacy.

Based on the PISA data of 2013 published by Organization Economic Cooperation and Development (OECD) shows that the level of literacy of Indonesian students' sciences is still low and below the OECD average.

Teachers, in learning chemistry are expected to motivate and guide students to observe and solve problems, so that a 
student cannot only work on questions and try the national exam perfectly, but also able to hone students' abilities or intellectuality to find and solve problems. Teaching and learning activities will achieve the curriculum 2013 goals if a teacher can choose and use learning models that are suitable for chemistry subjects, where students are expected to hone their skills to solve problems in order to improve their scientific processes skills. Therefore, researchers here choose guided discovery learning models. This learning model, requires students to know for themselves about the facts of the concept and connect with the knowledge they have finally able to develop science process skills.

Research on the use of guided discovery learning models for improving skills processes and conceptual understanding of the results of learning natural sciences [4], several advantages such as helping students develop inventory and mastering cognitive skills from the process, provides opportunities for students to move forward according to their abilities, as well as direct students to learn in their own way, allowing students to check ideas.

Understanding the learning process associated with science literacy can be improved. One of the solutions offered is the implementation of a learning method along with the development of tools that can provide ease, increase interest, motivation of students to learn chemistry and how to apply it properly and correctly. Selection of Guided Discovery learning model or guided discovery is one of the learning models that can increase student activity and establish effective interaction between student and teacher by using basic consideration that is: guided by purpose, individual difference of student, teacher ability, nature of lesson material, situation classes, completeness of facilities and advantages and disadvantages of learning methods [5]. Guided Discovery or guided discovery has strategic targets for: (1) maximal learner involvement in the learning process, (2) logical and systematic activity harassment on learning objectives and, (3) developing a self-confident attitude about what found [6].

Improving the learning process by developing learning tools is one of the efforts that can be taken to improve students' science literacy. PISA assesses science literacy through scientific competence that includes the ability to identify scientific issues that include the ability to identify problems, explain the phenomenon of science, and draw conclusions based on facts and science issues [7]. Learning tools that can train students' science literacy is needed to be developed.

Assessments in the PISA assessment focuses on reading, math, science and problem solving. In this study, it does not only ascertain whether students can know what they have learned, but also examines how well they can explore from what they learn and apply them both inside and outside school. Problems that are tested in the form of contextual problems that closely with everyday life. Based on the results of interviews with teachers at SMA Negeri 18 Surabaya, the teachers still find it difficult to develop learning tools in accordance with the demands of the 2013 curriculum. Learning tools that can train students' science literacy are needed to be developed. Result of National Final Examination in SMA Negeri 18 Surabaya has an average of 44,73.

Learning tools can be used as a tool to train students' science literacy if the learning tool allows students to explore their own knowledge. The results show that authentic science experiences can be used as a way to increase students' science literacy [8]. Students gain not only scientific knowledge from teachers, but they gain knowledge of science with their own invention. One learning model that provides learning opportunities for students to actively develop conceptual understanding by combining their knowledge with Guided Discovery Learning.

In this paper conducted research through the development of learning devices using Guided Discovery Learning model on hydrocarbon material in students of SMA Negeri 18 Surabaya. Model learning devices will be based on Guided Discovery Learning model, which will be validated by 3 (three) validators. After the validator stated that the learning device is valid then the learning device is then used as a learning process of teaching in the classroom with learning materials about hydrocarbons. Measurement of success will be seen by using the comparison of pre-test and post-test result.

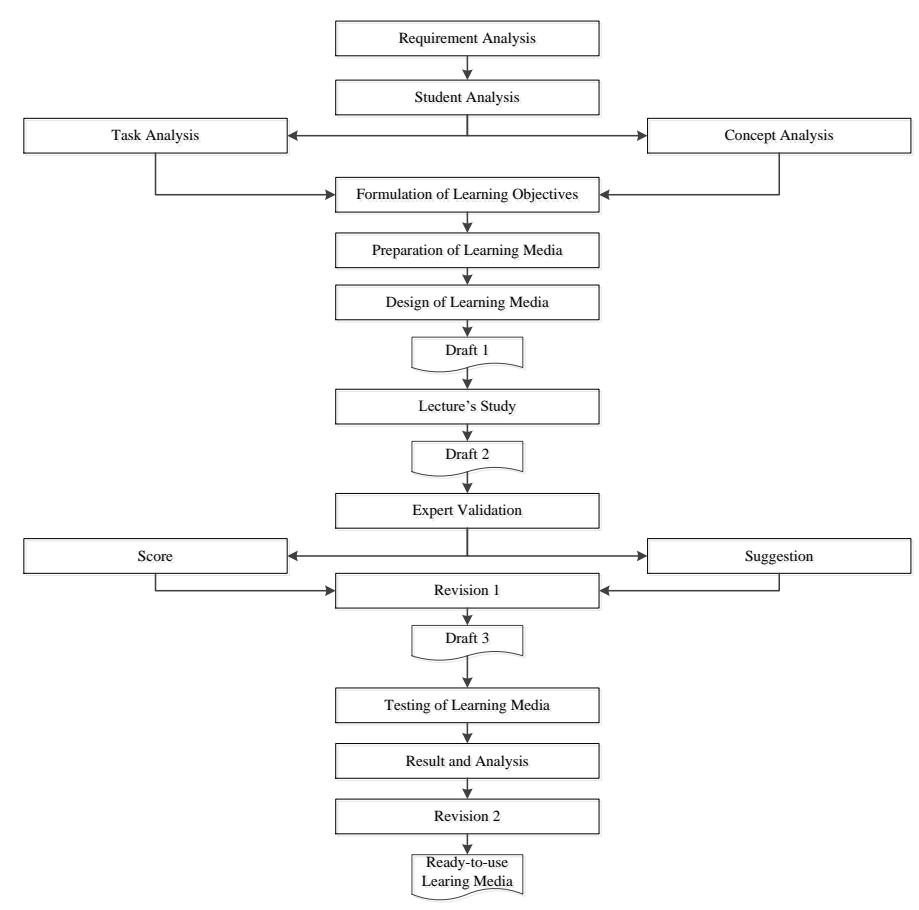

Figure 1: Learning Device Development Steps [9] 


\section{METHOD}

This research is divided into two stages namely the development of learning tools and the testing phase of application of learning tools. Learning tools consist of syllabus, lesson plan, textbook, student worksheet, and test results learning. The steps of developing learning tools, as in Figure 1, are divided into three sub-stages of define, design, and develop until the draft device that is ready to be tested formed.

Defining-stage is a stage to explain learning conditions. The steps in determining the stages include: needs analysis, student analysis, task analysis, concept analysis, and formulation of learning objectives. The formation of learning tools starting with Needs Analysis aims to raise the basic problems needed in developing learning tools. In the analysis phase of students, the researcher examines several characteristics of students to examine several characteristics of students to find out how much students' abilities for hydrocarbon materials will be studied, including: analysis of students' academic abilities, and analysis of students' maturity levels. Task analysis aims to identify the main skills that researchers will learn and analyze in a series of additional skills that may be needed. This analysis ensures a thorough review of tasks in the learning material [9].

Based on basic competencies, indicators and learning objectives a learning tool is developed. Achievement indicators are prepared to determine the success of achieving basic competencies. The formulation of indicators is also adjusted to the scientific competence of the achievement of learning outcomes tests. In the development stage (revision 1) aims to produce learning tools based on concept learning models on revised hydrocarbon materials based on input from supervisors and lecturer validation. Experiment device learning using One-Group Pre-test and Post-test Design, which is an experiment conducted in one group without comparison group [10].

A. Variable under study

The variables related to this research are:

- The validity of instructional devices

- Variables related to the practicality of learning devices

- Variables related to the effectiveness of learning devices

The validity of instructional devices is a score obtained from validator assessment of instructional devices by using instrument in the form of validation sheet and learning device declared eligible. Implementation of learning is an assessment by observers about the ability of teachers in implementing and managing all Lesson Plan by giving a score on the observation sheet of learning implementation.

Student activity during the learning process is the student activity that emerged during the learning took place. Constraints in learning excellence are constraints during learning activities that can be sourced from teachers, students, and infrastructure facilities observed by observers and identified by noting the constraints experienced in the available observation sheets. The ability to test learning outcomes is defined as the ability to use science knowledge to identify problems, explain science phenomena, and draw conclusions based on facts and science issues whose measurement refers to scientific competence.

Completeness of Student Learning Outcomes is the achievement of learning achievement obtained by students. Students 'responses are students' opinions on the learning device components that include the use of the device, the novelty of the device, the ease of the device, and the ease of test questions measured using a student response questionnaire expressed as a percentage.

\section{B. Research Instrument}

Instruments are tools used for reference to assess feasibility or to collect research data. Validated learning tools include: Syllabus, Lesson Plan, Student Worksheet, Student Book, Evaluation Sheet and Assessment Sheet. Validation is a process to improve, create, and develop based on development procedures that have been validated by validated experts including content validity, presentation, and language. Wisdom comes from a basic word like, self-executable word can mean something that is held and a special sign of an area [11]. It can be said that the word of commitment is more to the process, not a result. Learning as an activity organizes or regulates the environment best and connects it with students so that there is a learning process, this environment in this sense not only the study room, this environment in this sense not only the study room, but also includes teachers, props, libraries, laboratories, etc. that are relevant to student activities $[12,13]$.

\section{Data analysis technique}

Learning tools developed (Syllabus, Lesson Plan, Student Worksheet, Student Book, Assessment of Learning Outcomes) are validated using validation tools to determine the quality of feasibility and refinement before being tested. The validation scale is as in Table 1 [14]. Device validation is performed by 3 expert experts in the field of education by providing scoring scores and improvement suggestions for perfection of the device. Data validation results are analysed descriptively qualitative

TABLE I. VALIDATOR SCORE ASSESSMENT

\begin{tabular}{|c|c|}
\hline assessment & Score \\
\hline Very Low & 1 \\
\hline Low & 2 \\
\hline Good & 3 \\
\hline Very Good & 4 \\
\hline
\end{tabular}


III. RESULTS AND DISCUSSION

TABLE II. RESULT OF SYLLABUS ASSESSMENT

\begin{tabular}{|l|c|c|c|c|c|}
\hline \multirow{2}{*}{ Aspect of assessment } & \multicolumn{3}{|c|}{ Validator } & \multirow{2}{*}{ Average } & \multirow{2}{*}{ Criteria } \\
\cline { 2 - 5 } & V1 & V2 & V3 & & \\
\hline Subject identity & 4 & 4 & 4 & 4,00 & Very Good \\
\hline Learning Objective & 4 & 3 & 3 & 3,33 & Good \\
\hline Learning Activities & 4 & 4 & 4 & 4 & Very Good \\
\hline Time & 4 & 3 & 4 & 3,67 & Very Good \\
\hline $\begin{array}{l}\text { Suitability of the subject } \\
\text { matter and the indicator } \\
\begin{array}{l}\text { with the basic } \\
\text { competencies }\end{array}\end{array}$ & 3 & 4 & 4 & 3,67 & Very Good \\
\hline Assessment & 3 & 3 & 3 & 3 & Good \\
\hline Range syllabus & & & & $\begin{array}{c}3.00- \\
4.00\end{array}$ & Very Good \\
\hline
\end{tabular}

The syllabus developed by researchers refers to the Minister of Education and Culture Regulation (Permendikbud) concerning the Upper School Syllabus suggested in the curriculum 2013. The syllabus component includes core competencies, basic competencies, learning materials, learning activities, assessment, time allocation, and learning resources. The developed syllabus was then validated by a chemistry expert. Analysis of the data of the Syllabus assessment results briefly in Table 2. Seen in Table 2 the average value of the validator assessments is obtained by a good category

In addition to providing validator assessments also provide suggestions and feedback on the developed syllabus. Feedback from validators is presented in Table III.

\section{TABLE III. VALIDATOR SUGGESTION}

\begin{tabular}{|l|l|}
\hline \multicolumn{1}{|c|}{ Suggestion } & \multicolumn{1}{c|}{ Improvement } \\
\hline $\begin{array}{l}\text { Include semesters } \\
\text { on the syllabus }\end{array}$ & $\begin{array}{l}\text { Completing the identity of the syllabus by listing } \\
\text { the semester. }\end{array}$ \\
\hline Include Class & Complete class identity by listing class XI \\
\hline
\end{tabular}

The developed lesson Plan is 3 times the meeting, in accordance with the time allocation of hydrocarbon materials listed in the national syllabus. The developed lesson plan is further validated by 3 validators to provide an assessment and enter the Lesson plan. The results of the lesson plan feasibility assessment are summarized in Table IV.

\section{TABLE IV. RESULT OF LESSON PLAN ASSESSMENT}

\begin{tabular}{|c|l|c|c|c|c|c|}
\hline & \multirow{2}{*}{$\begin{array}{c}\text { Aspect of } \\
\text { assessment }\end{array}$} & \multicolumn{2}{|c|}{ Validator assessment } & Average & criteria \\
\cline { 3 - 7 } & & V1 & V2 & V3 & & \\
\hline 1 & Identity & 4 & 4 & 4 & 4 & $\begin{array}{c}\text { Very } \\
\text { Good }\end{array}$ \\
\hline 2 & Learning Objective & 3 & 3 & 4 & 3.33 & Good \\
\hline 3 & $\begin{array}{l}\text { Media, tools and } \\
\text { materials and } \\
\text { learning resources }\end{array}$ & 3 & 3 & 3 & 3 & Good \\
\hline 4 & Learning Activities & 3.67 & 3.67 & 4 & 3.78 & $\begin{array}{c}\text { Very } \\
\text { Good }\end{array}$ \\
\hline
\end{tabular}

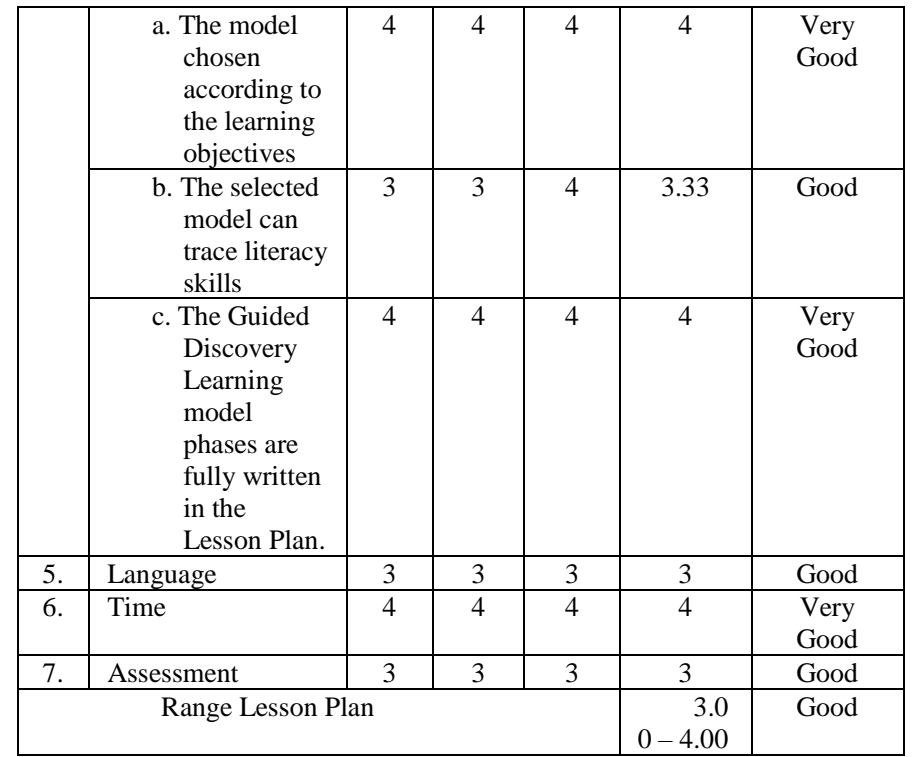

After the learning process using a learning device based on Guided Discovery Learning, students are awarded a post-test. The results of students' science literacy have improved in pretest and post-test activities. The results of the analysis of the completeness of the indicators can be seen in Table 5 with range of lesson plan value is about 3 to 4 with good criteria.

\section{TABLE V. RESULT OF SCIENCE LITERACY (PRE-TEST AND POST-TEST)}

\begin{tabular}{|c|c|c|c|c|c|c|c|c|}
\hline \multirow{3}{*}{$\begin{array}{l}\text { Stud } \\
\text { ent }\end{array}$} & \multicolumn{4}{|c|}{ completeness } & \multirow{2}{*}{\multicolumn{2}{|c|}{$\begin{array}{c}\text { Classical } \\
\text { completeness }\end{array}$}} & \multirow{3}{*}{$\begin{array}{l}\mathrm{N}- \\
\text { gain }\end{array}$} & \multirow{3}{*}{ Category } \\
\hline & \multicolumn{2}{|c|}{ Pre-Test } & \multicolumn{2}{|c|}{ Post-Test } & & & & \\
\hline & Result & Criteria & Result & Criteria & $\begin{array}{l}\text { Pre- } \\
\text { Test }\end{array}$ & $\begin{array}{l}\text { Post- } \\
\text { test }\end{array}$ & & \\
\hline 1 & 65 & $\mathrm{NC}$ & 90 & $\mathrm{C}$ & & & 0.71 & High \\
\hline 2 & 40 & $\mathrm{NC}$ & 90 & $\mathrm{C}$ & & & 0.83 & High \\
\hline 3 & 60 & $\mathrm{NC}$ & 85 & $\mathrm{C}$ & & & 0.63 & Medium \\
\hline 4 & 40 & $\mathrm{NC}$ & 85 & $\mathrm{C}$ & & & 0.75 & High \\
\hline 5 & 40 & $\mathrm{NC}$ & 95 & $\mathrm{C}$ & & & 0.92 & High \\
\hline 6 & 55 & $\mathrm{NC}$ & 100 & $\mathrm{C}$ & $\mathrm{NC}$ & $\mathrm{C}$ & 1.00 & High \\
\hline 7 & 55 & $\mathrm{NC}$ & 90 & $\mathrm{C}$ & & & 0.78 & High \\
\hline 8 & 45 & $\mathrm{NC}$ & 85 & $\mathrm{C}$ & & & 0.73 & High \\
\hline 9 & 50 & $\mathrm{NC}$ & 80 & $\mathrm{C}$ & & & 0.60 & Medium \\
\hline 10 & 35 & $\mathrm{NC}$ & 75 & $\mathrm{C}$ & & & 0.62 & Medium \\
\hline 11 & 60 & $\mathrm{NC}$ & 100 & $\mathrm{C}$ & & & 0.75 & High \\
\hline 12 & 60 & $\mathrm{NC}$ & 100 & $\mathrm{C}$ & & & 0.75 & High \\
\hline 13 & 50 & $\mathrm{NC}$ & 100 & $\mathrm{C}$ & & & 1.00 & High \\
\hline 14 & 55 & $\mathrm{NC}$ & 100 & $\mathrm{C}$ & & & 1.00 & High \\
\hline 15 & 30 & $\mathrm{NC}$ & 70 & $\mathrm{C}$ & & & 0.57 & Medium \\
\hline 16 & 30 & $\mathrm{NC}$ & 75 & $\mathrm{C}$ & & & 0.64 & Medium \\
\hline 17 & 45 & $\mathrm{NC}$ & 85 & $\mathrm{C}$ & & & 0.73 & High \\
\hline 18 & 45 & $\mathrm{NC}$ & 80 & $\mathrm{C}$ & $\mathrm{NC}$ & $\mathrm{C}$ & 0.64 & Medium \\
\hline 19 & 50 & $\mathrm{NC}$ & 80 & $\mathrm{C}$ & & & 0.60 & Medium \\
\hline 20 & 50 & $\mathrm{NC}$ & 85 & $\mathrm{C}$ & & & 0.70 & High \\
\hline 21 & 30 & $\mathrm{NC}$ & 75 & $\mathrm{C}$ & & & 0.64 & Medium \\
\hline 22 & 30 & $\mathrm{NC}$ & 80 & $\mathrm{C}$ & & & 0.71 & High \\
\hline 23 & 50 & $\mathrm{NC}$ & 75 & $\mathrm{C}$ & & & 0.5 & Medium \\
\hline 24 & 60 & $\mathrm{NC}$ & 90 & $\mathrm{C}$ & & & 0.75 & High \\
\hline 25 & 55 & $\mathrm{NC}$ & 100 & $\mathrm{C}$ & & & 1.00 & High \\
\hline
\end{tabular}


Table $\mathrm{V}$ shows that at the time of the pre-test there was no complete indicator, with the lowest score 30 and the highest score 65 After the learning was done with the tools developed on the post-test all the completed indicators $(100 \%$ of students completed), with the lowest 70 and the highest 100.

\section{CONCLUSION}

Based on the data and discussion of research results, it can be concluded that the learning tools based on Guided Discovery Learning developed has been declared valid, practical, and effective to trained science literacy seen in the value of the completeness of the pre-test and post-test increases

\section{REFERENCES}

[1] American Association for the Advancement of Science, Science for All Americans, Oxford:Oxford University Press, 1990.

[2] UNESCO, Science Education Policy-Making Eleven Emerging, issues S.1.: UNESCO, 2008.

[3] N. Khasanah, S. Dwiastuti, Nurmiyati, "The Infuence of Guided Discovery Learning Model Toward Scientific Literacy Based On Naturalist Intelligence", Proceeding Biology Education Conference, vol. 13, no. 1, pp. 346-351, 2016.
[4] E. Kamiludin, Upaya Keterampilan Proses dan Pemahaman Konsep IPA (Fisika) Melalui pendekatan Guided Discovery Laboratory Lesson Siswa Kelas VIII SMP Negeri 4 Ciamis, Skripsi, Yogyakarta : UIN Sunan Kalijaga, 2009.

[5] S. B. Djamarah, Guru dan Anak Didik Dalam Interaksi Edukatif, Jakarta: Rineka Cipta, 2000.

[6] A. Achmadi dan J. T. Praetya, SBM (Strategi Belajar Mengajar), Bandung : Pustaka Setia, 1993.

[7] A. Achmadi dan J. T. Praetya, "PISA 2012 Result: What Students Know and Can Do-Student Performance in Mathematics, Reading, Science", vol. 1, 2012.

[8] M. V. Ejick and W. M. Roth, "Authentic Science Experiences as A Vehicle to Change Students' Orientations Toward Science and Scientific Career choices: Learning From The Paths Followed by Brad", Cultural Studies of Science Education, vol. 4, Issues 3, Pp. 611-638, 2009.

[9] S. Thiagarajan, D. S. Semmel, and M. I. Semmel, Instructional Development for Training Teachers of Expectional Children, Minneapolis, Minnesota: Leadership Training Institute/Special Education, University of Minnesota, 1974

[10] Sugiyono, Metode Penelitian Kuantitatif, Kualitatif dan R\&D, Bandung : Alfabeta, 2009.

[11] Depdiknas, Panduan Pengembangan Model Pembelajaran Berbasis Kompetensi, Jakarta: Direktorat PPTK dan KPT Dirjen Dikti, 2005.

[12] S. Nasution, Berbagai Pendekatan Dalam Proses Belajar Mengajar, Jakarta : Bumi Aksara, 2000.

[13] Sugihartono, Psikologi Pendidikan, Yogyakarta: UNY Pers, 2007.

[14] B. H. M. Bungin, Penelitian Kualitatif : Komunikasi, Ekonomi, Kebijakan Publik, dan Ilmu social, Jakarta : Kencana Prenama Media Group, 2007. 